\title{
608 ガゾリンポートインジェクタによる壁面衝突噴霧の液膜厚さ計測
} Mesurement of the Liquid Fuel Thickness Formed by Impinging Spray on a Wall Using Port Injectors

\author{
山田 友洋（千葉大） \\ ○正 森吉 泰生（千葉大） \\ 正 窪山 達也 (千葉大) \\ 佐藤 岳 (株式会社ケーヒン)
}

Tomohiro YAMADA, Yasuo MORIYOSHI, Tastuya KUBOYAMA

Chiba University, 1-33, Yayoi-cho, Inage-ku, Chiba-shi,, Chiba

Gaku SATO, Keihin Corp, 1-26-2-39F, Nishishinjyuku, Shinjyuku-ku, Tokyo

\begin{abstract}
In gasoline engines, port injected fuel impinges on the wall of intake port and intake valves. Adhered fuel affects exhaust emissions. It is important to understand the liquid fuel thickness and its area formed by impinging on a wall for the decision of injector position and characteristics. In this paper, the liquid fuel thickness formed by impinging on a flat wall was measured using laser induced fluorescence method. The effect of properties of spray and the distance between the injector and the flat wall on the liquid fuel thickness and its area was investigated. The result shows that the liquid fuel is distributed in a ring shape at any distance and with any injector type. The less the hole of nozzle is, the less the fuel attachment takes.
\end{abstract}

Key Words: Fuel Injection, Spray, Fluorescence, Spray Angle, Liquid Film

\section{1. 緒言}

近年，地球環境保護への関心が高まり，自動車用エンジ ンに対して徹底した排気清浄化が求められている。ポート 噴射ガソリンエンジンにおける排気清浄化の取り組みの 1 つとして，冷間始動時の排出ガスの有害物質である HC の 低減が重要な課題として研究されている(1). ポート噴射で は, 吸気ポート壁面やシリンダ壁等への燃料付着は避けら れず，これが末燃 $\mathrm{HC}$ の排出原因となることが報告されて いる(2). よって, インジェクタの最適な搭載位置や噴霧性 能を決定する上で然料付着を考虑することは重要な設計要 素である. 燃料付着は特に, 壁面への衝突挙動と関係する ことから多くの実験や計算の研究がなされているが,粒径, 噴霧速度, 噴霧特性の異なるインジェクタをパラメータと した研究例はあまり見られない，そこで本研究では，噴霧 性能の異なるインジェクタが壁面衝突による液膜形成に及 ぼす影響について明らかにすることを目的とし，壁面衝突 噴霧の液膜厚さとその面積を計測する.

\section{2. 実験装置及び実験方法}

2.1 供試ノズル

本研究では噴霧特性の異なる 3 種類の供試ノズルを用い る. TYPE A,B,C の順に, 噴孔数は 6, 4, 1, 噴霧角は 40, 24，1であり，流量はどれもほぼ同じである.

2.2 実験方法

液膜厚さはレーザ誘起蛍光 (LIF) 法の原理を用いて計測 した。ここでは, 液膜面に対して水平横方向からレーザシ 一トを照射し，蛍光を発する液膜をレーザシートに対し垂 直方向から撮影することにより液膜厚さを計測する．蛍光 のみを捉えることで壁面や液膜表面付近からの散乱光等の ノイズを防ぎ液膜の抽出が出来る. 図 1 に実験装置の概略 を示す.レーザは Ar レーザ（COHERENT 社製, I307C, 波長 $514 \mathrm{~nm}$, 出力 $1.9 \mathrm{~W}$ ）を用い，2枚のシリンドリカルレ ンズにより, 幅約 $1.5 \mathrm{~mm}$, 厚さ約 $0.32 \mathrm{~mm}$ のシート状にし て液膜面に照射する．燃料にはイソオクタンを用い，蛍光 剂としてローダミン $6 \mathrm{G}$ を用いる。この時, 蛍光剤を燃料 中に溶かすためにエタノールを 10vol\%添加した. 雲囲気圧 力は大気圧, 雲囲気温度は室温 $\left(25^{\circ} \mathrm{C}\right)$ とし, 燃料は $\mathrm{N}_{2}$ によ り $343 \mathrm{kPa}$ に加圧し, 噴射期間は $10 \mathrm{~ms}$ とした. ガソリンポ 一トインジェクタから噴射された燃料は，25,50および
$75 \mathrm{~mm}$ 離れた壁面に垂直に衝突させ, 燃料液膜を形成させ る.これにレーザを照射し, 液膜からの蛍光を高速度カメ ラ（Photron 社製，APX RS, 1000fps, 1024×1024pixels）を用 いて撮影する. 高速度カメラの前には, 散乱光を除去し液 膜からの波長 $570 \mathrm{~nm}$ 付近の蛍光を捉えるためにシャープ カットフィルタ（シグマ光機製，SCF-50S-56O）を設置す る.なお，本実験で壁面の温度は $25^{\circ} \mathrm{C}$ とた。

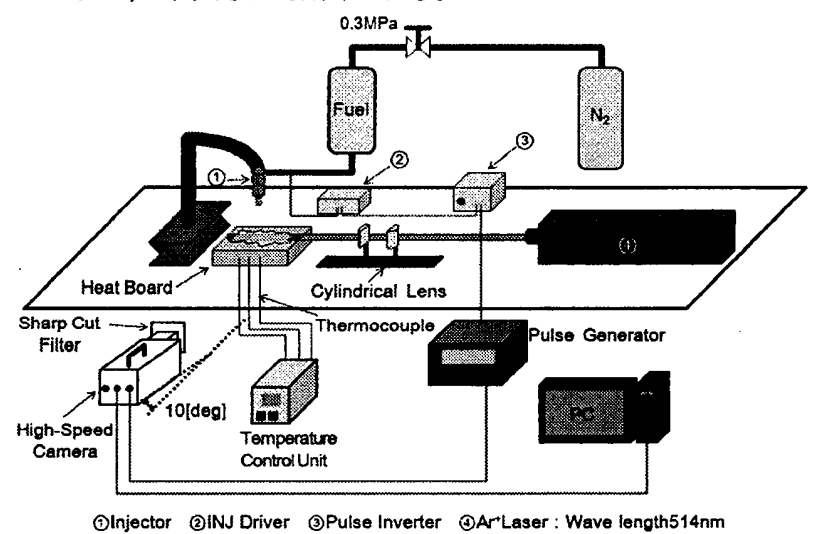

Fig.1 Experimental apparatus

\section{3 解析方法}

ノズル直下を原点とし，レーザシートに水平な方向を $x$, 垂直な方向を $y$ とする. インジェクタを $y$ 方向に任意の距 離ずらすことで計測面を変更し,また $x$ 方向に $5 \mathrm{~mm}$ 間隔ず つずらしながら液膜からの蛍光の撮影を行うことで, その 計測面上の全ての液膜厚さを計測する。 また，1つの計測 位置で 10 回ずつ撮影を行い, 10 回の平均液膜厚さを結果 として用いる。実験時間の都合上, TYPE A,B では全液膜 付着範囲に対し半面での計測とした.

実験での一回の撮影範囲は約 $5 \mathrm{~mm} \times 5 \mathrm{~mm}$ であり，この時 の空間分解能は $4.80 \mu \mathrm{m} \sim 4.82 \mu \mathrm{m} / \mathrm{pixel}$ に相当する. 液膜厚 さを解析する際，一回の撮影範囲を $x$ 軸方向に 4 分割し， それぞれ $x$ 軸方向に $1.25 \mathrm{~mm}$ の範囲内での最大液膜厚さを 計測し，これを分割した各中心位置における液膜厚さとし た.なお, 厚さ $96.5[\mu \mathrm{m}]$ と $126[\mu \mathrm{m}]$ の OHP シートを用いて, 本計測法による厚さ計測の検定試験を行った結果, ばらつ きはそれぞれ最大で $10 \%$ あっった。

日本機械学会関東支部第 18 期総会講演会講演論文集 ['12.3.9-10,習志野] 
液膜付着面積算出方法に関しては, 一定以上の液膜厚さ が計測された点において, 各 $x, y$ 方向の計測閒隔で囲まれ る領域をその計測点における付着面積と近似し，それを全 計測領域で足し合わせ，全体の付着面積とした。

\section{3. 実験結果及び考察}

3.1 噴霧性能および噴射高さの違いが液膜分布に及ぼす 影響

噴射高さ $\boldsymbol{b}$ を 25,50 および $75 \mathrm{~mm}$ と変化させ TYPE A,B およびCのノズルについて液膜厚さ分布を計測した.なお， 3 つの中で液滴速度の小さな TYPE A では, 噴射開始後 $80 \mathrm{~ms}$ 付近まで壁面に衝突した後のはね返り液滴等が確認 された為, 全てのタイプのノズルで液膜厚さが計測できる 噴射開始後 $100 \mathrm{~ms}$ における液膜厚さを計测した。まず，液 膜分布の例として，図 2 に噴射高さ $75 \mathrm{~mm}$ での TYPE C に ついての結果を示す. TYPE C はほぼ液柱状に燃料が壁面 に衝突するが図に示すように，ノズル直下付近では液膜を 形成せず，リング状に液膜が分布することがわかる.

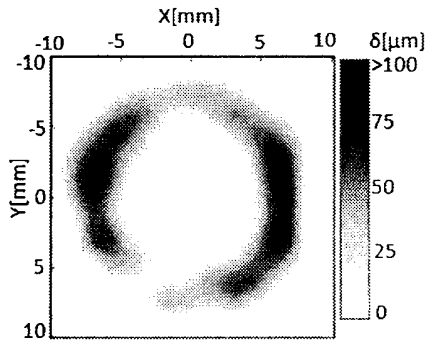

Fig.2 Liquid fuel thickness of TYPE C

全条件において液膜厚さを計測し, 最小 $3.5 \mu \mathrm{m}$ 以上の平 均液膜厚さをまとめた結果を図 3 に示す。いずれのタイプ の供試ノズルにおいても, 形成された液膜形状は，中心の 厚さが薄く外側が厚くなる．ただし，TYPE B の $h=25 \mathrm{~mm}$ においては，噴孔に対応した 4 つの楕円状液膜が 1 つにな ったと考えられるため, このようにはならない. TYPE C では噴射高さ $h$ が変化しても平均液膜厚さほとんど変化し ないが, TYPE A,B では噴射高さ $h$ が短くなるほど平均液 膜厚さは厚くなる.

また噴射高さ別に着目すると，噴射高さ $h$ が大きい場合， 噴孔数が多いノズルほど液膜厚さは小さくなる。また，噴 射高さ $h$ が小さい場合, 噴孔数が少ないノズルほど, 壁面 衝突速度が大きいため, 壁面衝突による液滴の跳ね返り量 が多くなり, 液膜厚さの増加が抑えられると考えられる.

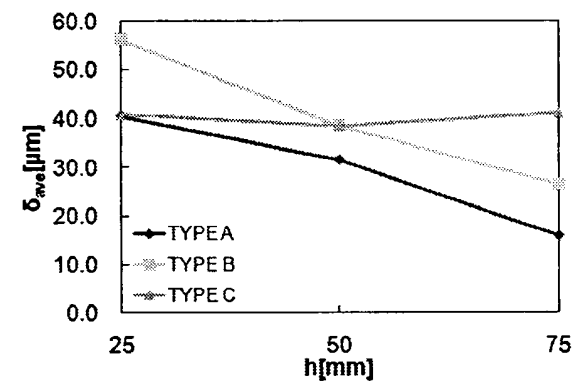

Fig. 3 Comparison of the liquid fuel thickness

\section{2 液膜付着面積}

液膜厚さに加え, 液膜存在領域を定量的に明らかにする ために液膜付着面積 $S$ を求めた。全条件で算出した液膜付 着面積の結果を図 4 に示す.

TYPE A の付着面積は $h=75,50 \mathrm{~mm}$ では近い值に対し, $h$ $=25 \mathrm{~mm}$ の時のみ減少した.これは, $h=25 \mathrm{~mm}$ になると壁面
衝突前の液滴速度が速くなり，壁面衝突による中心付近で の跳ね返りが多くなったためと考えられる. TYPE A の付 着面積は, どの高さにおいても TYPE B の 2 倍以上, TYPE $\mathrm{C} の 3$ 倍以上となった.

TYPE B の付着面積も, $h=75,50 \mathrm{~mm}$ では近い值に対し, $h=25 \mathrm{~mm}$ の時のみ付着面積は減少した. TYPE A 同様の理 由が考えられる。

TYPE C の付着面積は噴射高さ $h$ によらずほぼ同等であ った.

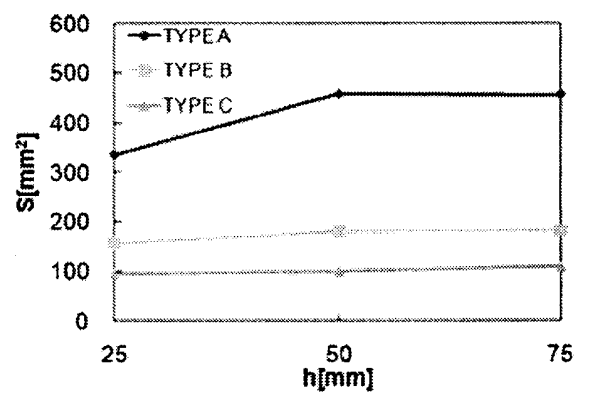

Fig.4 Comparison of adhesion areas

\section{3 液膜付着率}

これまで計測した液膜厚さおよび液膜付着面積から付着 体積を算出し，付着率を図 5 にまとめた。図より，噴射高 さによらず噴孔数が少ない（噴霧角が小さい）ノズル程付 着率が小さくなることから，噴孔数が少ないノズルほど壁 面に付着しにくい。 また，多噴孔ノズルでは TYPE Aの $h$ $=50 \mathrm{~mm}$ を除いて噴射高さを大きくする程壁面に付着しに くいと言える。

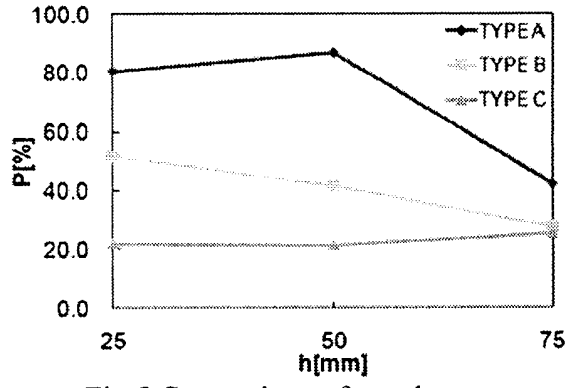

Fig. 5 Comparison of attachment rates

\section{4. 結論}

噴霧特性の異なる 3 種類の供試ノズルを用いて，噴霧特 性および噴射高さ $h$ の違いが液膜厚さおよび付着面積に及 ぼす影響について調查した結果, 以下の知見を得た。

(1) 噴孔数の違いによらず形成された液膜分布は中心の厚 さが薄く外側が厚くリング状に分布する. 単噴孔ノズ ルでは噴射高さが変化しても平均液膜厚さおよび夜膜 形状はほとんど变化しないが，多噴孔ノズルでは噴射 高さが短くなるほど平均液膜厚さは厚くなり，液膜形 状も大きく変化する。

（2）噴射高さによらず噴孔数が多い（噴霧角が大きい）， ズル程，付着面積は大きくなる.

(3) 噴射高さによらず噴孔数が少ない（噴霧角が小さい） ノズル程壁面に付着しにくい，また，多噴孔ノズルで は噴射高さを大きくする程，壁面に付着しにくい.

参考文献

(1) Takeda, K., et al. : SAE Tech.Pap.Ser.,No.950074,(1995)

(2) 山口ら：自動車技術会 学術講演前刷集 951(1995)

(3)開発ら：自動車技術会 学術講演前刷集 20095221 (2009) 